RESEARCH

\title{
Research Corrigendum
}

\section{Rapidly maturing variants of the Discosoma red fluorescent protein (DsRed)}

B.J. Bevis and B.S. Glick

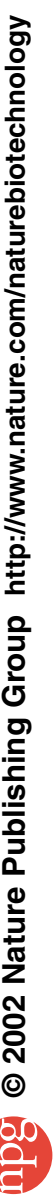

Nat. Biotechnol. 20, 83-87 (2002).

On p. 83 of this report, the authors stated that the $\mathrm{N} 42 \mathrm{H}$ mutation of DsRed accelerates chromophore maturation, but has the side effect of increasing the green emission. This spectral change caused by the $\mathrm{N} 42 \mathrm{H}$ mutation had previously been described by Wiehler $e t$ al. (cited as reference 15) and should have been credited accordingly. The authors regret the omission. 